\section{Annals of Spiru Haret University \\ Economic Series \\ Since 2000 \\ ISSN: 2393-1795 ISSN-L-2068-6900}

ICCS

Issue 1/2016

\title{
STUDIES ON THE MATERIALITY AND AGGREGATION, COMPENSATION AND OFFSETTING IN FINANCIAL STATEMENTS
}

\author{
Liana GĂDĂU \\ "Spiru Haret" University, Ion Ghica, no. 13, \\ Bucharest, 030045, Romania \\ Tel: +40214551000, Fax: +40213143900 \\ Email: lianagadau@yahoo.com
}

\begin{abstract}
The accounting principles should be considered an essential element in the preparation and presentation of financial statements, with our analysis focusing especially on the relative principles: materiality and aggregation, compensation and offsetting. We consider necessary to improve the analyzed concepts by bringing additional information, as clear and comprehensive as possible, information used as reference in the preparation of financial statements. Moreover, is crucial to apply a unitary thinking of the accounting referential which is linked to these accounting principles.

The research methods used in analyzing the principles are: documentation of theoretical study of normative acts in the field of accounting, observation, comparative analysis, synthesis, information classification and data interpretation.

Key words: materiality and aggregation; compensation and offsetting; significant accounting information; professional judgment in assessing materiality; incidence on the accounting processing; incidence on the presentation of financial statements.
\end{abstract}

JEL Classification: M40, M41 


\section{Annals of Spiru Haret University \\ Economic Series \\ Since 2000 \\ ISSN: 2393-1795 ISSN-L:2068-6900}

Issue 1/2016

\section{Introduction}

An important topic of the debate which completes the preparation and presentation of financial statements analysis is the analysis of accounting concepts which are the benchmark in financial statements for all countries with market economies, regardless of the accounting system to which they relate.

In the following we want to analyze the relative principles of financial statements as follows: materiality and aggregation, compensation and offsetting. We plan to conduct an objective analysis and critical content of these accounting principles, with the support precision found in IAS 1 Presentation of Financial Statements and IASB Framework, but also to provide a qualitative analysis which will achieve permanent connections with other referential accounting, but also with the specific literature.

\section{Literature Review}

The subject of the paper is current for accounting. The paper in based on a rich and current bibliography, for example, Glăvan, E., M., et al., Contabilitate financiară, Bucureşti: Editura ASE, 2013, Iacob, P., Gheorghe, B., Contabilitatea financiară, București: Editura Intelcredo, 2014, Guşe, G.R., Valoare, preț, cost şi evaluare în contabilitate, București: Editura CECCAR, 2011, ISSB, Standardele Internaționale de Raportare Financiară, București: Editura CECCAR, 2015, etc. The subject of article is deepened by author in various works that underlie the doctoral thesis.

\section{The Relative Principles of the Financial Statements}

\subsection{The Significance Threshold}

The significance threshold is at the base in building the concept of true and fair view (fair presentation) of British accounting, hence being taken as a general feature of international reference. Please note that the European accounting concept of materiality is not listed explicitly among the principles defined in the European Accounting Directives also not among the principles of national accounting. At the conceptual accounting framework level, either international or the U.S., the materiality is presented as part of the qualitative characteristics of financial statements, specifically as a component of the relevance of the information. 


\section{\% Annals of Spiru Haret University \\ Economic Series \\ Since 2000 \\ ISSN: 2393-1795 ISSN-L:2068-6900}

ICCS

Issue $1 / 2016$

It means that the information is considered significant when the person who uses it reacts differently than if they did not have access to it. Here we find assessing the significance of information by omission or inaccuracy of its consequences on the economic decisions that users take based on the financial statements.

When assessing whether an item is material or not, we evaluate both the nature and size of the item. In assessing the significance of an item, depending on the specifics of each situation, it is possible that either nature or its size is the determining factor, or combination of effects generated by the two, as in the following example. After the financial control to an entity, fines of 50.000 lei were given. In terms of share of fines in the total expenditure $(0.4 \%$ of them $)$ the value of the fines can be considered insignificant. However, such penalties are received for irregularities found in the activity carried by the company, and can be considered significant in nature, making their separate presentation in the income statement.

At the international standard IAS 1 we find that the concept of materiality is related to the notion of aggregation. In this regard, it is noted that the financial statements result from processing large volumes of transactions that through aggregation are structured on groups according to their function or nature, resulting in a presentation of condensed and classified data, which form line items in the financial statements. It also states that if an item is not individually material, it is aggregated with other items either in the financial statements or in the notes.

If no element is sufficiently significant to be presented separately in the financial statements may be presented separately in the Notes.

The above requirements stipulated by the concept of materiality and aggregation of IAS 1, we see that this framework provides only disclosure in the financial statements, not the tools and guidance necessary to help the analysis to know whether or not an item is individually significant, or when is not sufficiently significant. Even if they say that these analyses are based on judgment, training specialists consider filling that need guiding principle for assessing significance, in as many specific situations. The fact that international practice has developed several usages (more or less objective) in calling professional 


\section{A Annals of Spiru Haret University \\ Economic Series \\ Since 2000 \\ ISSN: 2393-1795 ISSN-L:2068-6900}

Issue 1/2016

judgment in assessing materiality it proves that it takes these levers/directions.

We consider important that such guidance is found in IAS 1. These guiding do not restrict freedom of judgment, but provides a foothold for a qualified approach of the problem. This should be considered in the context of reasoning about materiality depending on the specific circumstances of each case. An amount deemed insignificant in a situation may be significant otherwise. Therefore, the judgment of materiality must take into account the nature of the item, its value and its share in total assets, income, liabilities, costs, size of business entity and other appropriate indicators. Also, the requirements of materiality and aggregation have an impact both on the presentation of financial statements and the accounting processing targeting relevant information as possible (overlapping or not the values by highlighting aggregate or their value). We find that the use of materiality helps to simplify the processing of accounting information, but great care must be taken to the results obtained, and how useful they are for all users in the proposed format. But in applying the concept of materiality one cannot go solely on the quantitative aspect, it implies a qualitative aspect as well. For example, in terms of quality, materiality should be considered when there are presented the accounting policies in the notes when an incomplete or incorrect presentation can lead to misinterpretation of these policies. Another example is the qualitative approach, and that when a line item includes structures considered important values, its components are detailed in the Notes to the financial statements.

If we extend the notion of significant research and other standards for presentation of financial information, another standard is IAS 8 Accounting Policies, Changes in Accounting Estimates and Errors. Under IAS 8, a significant statement is made about significant errors in previous periods later discovered in the current period to be corrected retrospectively in the first set of financial statements authorized for issue after their discovery. Significant error correction is made retrospectively by restating the comparative amounts for the prior period presented in which the error occurred, or if the error occurred before the earliest prior period presented, 


\section{Annals of Spiru Haret University \\ Economic Series \\ Since 2000 \\ ISSN: 2393-1795 ISSN-L:2068-6900}

ICCS

Issue 1/2016

by restating the opening balances of assets, liabilities and equity for the earliest prior presented period.

Another standard that focuses on the concept of materiality is IAS 10

Events after the Reporting Period. The rule requires that events after the balance sheet date are disclosed if they are of such importance that their failure would affect users' ability to make assessments and take decisions. For such significant events shall be disclosed in the Notes, the nature and an estimate of the financial effect of this significant event. We give some examples of such events: announcing a plan to discontinue an operation, start implementing a major restructuring, significant changes in asset prices or foreign exchange rate, changes in tax rates, tax laws - all these events occurring after the balance sheet date. Setting new rules is part of the standards that make direct reference to materiality, but if you look at all the rules, you can say that whenever the application is free of judgment there is the need to determine a threshold for significance.

The national accounting regulations - as evidence of Romanian setters's concern near international accounting referential requirements, have the concept of materiality treatment. This is the argument based on the following findings. Thus, both IASB Framework and the Finance Order no. 1802/2014 regarding the Approval of the Accounting Regulations on the annual individual and consolidated financial statements present the concept of materiality as a component of qualitative characteristics of financial statements, information relevance. The definition of significant information is the same as that seen in the IASB Framework, and IAS1, IAS 8, depending on the consequences of its omission or inaccuracy on the economic decisions that users take based on the financial statements. Also includes the significance of an item taking into account the nature and size of the item.

From the study we find out that no standard provides a quantitative threshold or limits the approximate appreciation of what is considered significant. The financial analysts proposed, in assessing the value of information, the use of a significant number of indicators for profitability, solvency, and liquidity. In the usual practice, is more common to report the value of the item to the total group to which it belongs. Based on the assessments of significance offered by different analysts, in the international 


\section{HDV \\ Annals of Spiru Haret University \\ Economic Series \\ Since 2000 \\ ISSN: 2393-1795 ISSN-L:2068-6900}

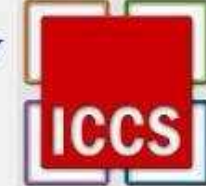

Issue 1/2016

accounting practices have been developed several usages, adopted by the majority of the literature. Bibliography referred to some of these works. We present these routines used in practice, in assessing the significance of the value of information in Table no. 1.

Table no. 1. Quantitative threshold limits in assessing the significance of an item

\begin{tabular}{|l||l||}
\hline Quantitative thresholds limits & $\begin{array}{l}\text { Assessing the significance of the } \\
\text { item }\end{array}$ \\
\hline $\begin{array}{l}\text { For element values }<5 \% \text { of a } \\
\text { representative indicator }\end{array}$ & $\begin{array}{l}\text { The element generally considered } \\
\text { insignificant }\end{array}$ \\
\hline $\begin{array}{l}\text { For element values } \geq 10 \% \text { of a } \\
\text { representative indicator }\end{array}$ & $\begin{array}{l}\text { The element generally considered } \\
\text { significant }\end{array}$ \\
\hline $\begin{array}{l}\text { For the element values in the range } \\
{[5 \%, 10 \% \text { of the value of a }} \\
\text { representative indicator }\end{array}$ & $\begin{array}{l}\text { The element generally considered } \\
\text { significant }\end{array}$ \\
\hline
\end{tabular}

Source: Author's own work

We find that the usage limits propose quantitative thresholds. However, we believe that such quantitative limits are to be applied carefully to each case, and not easily generalized.

For a more realistic believe should be taken into account the qualitative factors, the degree of risk faced by the entity, the nature, frequency element, possible long-term effects, the cumulative effect if similar elements etc.

\subsection{Compensation and Offsetting Principle}

Compensation and offsetting principle is another principle that should be taken into account in the preparation and presentation of financial statements. We note that no accounting referential explain what these terms mean.

The definition of offsetting principle is universally expressed in all accounting reference except the Fourth Directive, and it is: "the compensation 


\section{An Anals of Spiru Haret University \\ Economic Series \\ Since 2000 \\ ISSN: 2393-1795 ISSN-L:2068-6900}

ICCS

Issue 1/2016

of assets with liabilities or income with expenditure is not accepted", with some exceptions. Understanding the meaning of the contents principle tends to limit the compensation to deduct debts from assets, net revenue expenditure.

The Fourth Directive among valuation rules (principles of accounting referential other than valuation rules are equivalent to the Directive) provides no reference to offsetting time.

In the accounting literature, there are opinions that the rule of evaluation from the Directive "components of asset and liability items must be valued separately" is very close to the offsetting principle of international reference.

Further information is considered necessary to define the concepts. This separation of concepts is evidenced in the national referential by 1802/2014 regarding the Approval of the Accounting Regulations on the annual individual and consolidated financial statements that deals with two distinct principles, the offsetting and separate evaluation of assets and liabilities.

IAS 1 Presentation of Financial Statements allows exceptions to the offsetting principle in cases where an International Accounting Standard permits or requires such compensation. IAS 1 explains the effects of compensation in cases of comprehensive income or financial position or profit and loss account if is presented separately, by reducing the ability of users to understand the conditions under which these transactions took place, by decreasing capacity of the entity's future cash flows. IAS 1 specifies that the decrease in the value of assets impairment of inventories, accumulated depreciation, the value adjustments to receivables are not cases of compensation.

From the study we find out that netting accounting standards permits exceptions to a set of standards that we want to highlight. Thus, IAS 18 Revenues allows the following exceptions: presentation of sales revenue at the fair value of the consideration received, net of trade discounts granted by the entity; presentation of gains and losses on disposal of assets by deducting from the proceeds on disposal the carrying amount of the asset and the costs for sale.

Another exception to the offsetting principle found in IAS 11 Construction Contracts on reporting payments related to development work on long-term construction contracts. Under this standard, such 


\section{HDV \\ Annals of Spiru Haret University \\ Economic Series \\ Since 2000 \\ ISSN: 2393-1795 ISSN-L:2068-6900}

\section{Issue 1/2016}

payments and advances may decrease the value of the construction works being carried out, but can present additional information: values deductions and advances received, the aggregate amount of costs, profits recognized on the balance sheet (exception to the offsetting principle of payments reporting about the progress of work on long-term construction contracts specified by IAS 11 Construction Contracts).

Another standard excuse for the offsetting principle is IAS 20 Accounting for Government Grants and Disclosure of Government Assistance - allowing deduction of subsidy for active asset's carrying value. The grant is recognized as income over the life cycle of a depreciable asset by reducing the depreciation charge.

The offsetting principle that must be respected by the Romanian companies in financial statements is set out on the same core found in international referential, but with some features of the Romanian specialists. If international reference links to certain elements in certain situations (different set of standards) their degree of significance, this is not specified in the content of offsetting principle. OMFP no. 1802/2014 allows eventual compensations between receivables and payables, but compared to the same entity, which can be made only after proper accounting for revenue and expenses.

We believe that, without further information on situations in which may be allowed such compensation, and the law makes no reference to the significance of the elements of claims and liabilities of their offsetting, the national reference system provides incomplete data in defining this principle and must take into account preparatory financial statements. An improvement in principle, but insufficiently, was made by the Order no. 1802/2014 regarding the Approval of the Accounting Regulations on the annual individual and consolidated financial statements by adding specifications such as: the exchange of assets, the mutual provision of related services operations must be recorded separately in accounting, so no compensation is allowed between them.

\section{Conclusions}

In conclusion, the concept of materiality in financial statements is recognized and improved by all reference of accounting, and it stands best in the Romanian referential which significantly supplemented this concept in order to get near the international referential requirements. 


\section{Annals of Spiru Haret University \\ Economic Series \\ Since 2000 \\ ISSN: 2393-1795 ISSN-L:2068-6900}

ICCS

Issue 1/2016

We maintain our point of view, namely that we consider necessary the introduction of guidance for various specific situations for all accounts. Although accounting practices have developed routines to determine the significance value of a financial statement, we believe that it should be approached with caution and not applied in a rigid and generalized manner, but taking into consideration the size, the characteristics of the entity and the specific situation in which that is, the nature of the frequency of the analyzed element. The impact of materiality principle best reflects the content of explanatory notes, as most items in this financial situation entail application of the both quantitative and qualitative sides.

After analyzing all aspects of the offsetting principle, from its definition to the features, details presented by reference of analysis on this principle, we can argue its importance in preparing the financial statements through the following ideas. The offsetting principle supports the requirement for full and complete accounting information. Following this principle can ensures transparency of information, thus evaluation and separate accounting record of assets, liabilities, equity, income and expenses. The importance of this principle in financial statements preparation is substantiated by the fact that it involves finding a quite optimal ratio between quality of information and level of detail. It also allows presenting the financial statements and the integrity of relationships with the third parties during the exercise to maintain relationships between physical flows and financial flows. It is therefore necessary to provide a national reference system as full-offsetting principle.

\section{References}

1. Feleagă, N. et al. (2008), Politici şi opțiuni contabile, Bucureşti: Editura Infomega.

2. Gădău, L. (2014), Întocmirea, prezentarea şi utilizarea situațiilor financiare. Studii şi cercetări, Bucureşti: Editura Tribuna Economică.

3. Glăvan, E. M., Păunescu, M., Calu, D.A. (2013), Contabilitate financiară, Bucureşti: Editura ASE.

4. Guşe, G.R. (2011), Valoare, preț, cost şi evaluare în contabilitate, București: Editura CECCAR. 


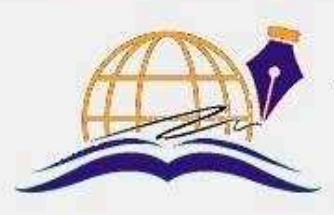

\section{Annals of Spiru Haret University}

Economic Series

Since 2000

ISSN: 2393-1795 ISSN-L:2068-6900

\section{Issue 1/2016}

5. Iacob, P., Gheorghe, B. (2014), Contabilitatea financiară, Bucureşti: Editura Intelcredo.

6. IASB (2015), Standardele Internaționale de Raportare Financiară, București: Editura CECCAR.

7. Ristea, M. et al. (2009), Contabilitatea societăților comerciale, Bucureşti: Editura Economică.

8. IAS 1 Presentation of Financial Statements.

9. IAS 8 Accounting Policies, Changes in Accounting Estimates and Errors.

10. IAS 10 Events after the Reporting Period.

11. IAS 18 Revenues.

12. IAS 11 Construction Contracts.

13. IAS 20 Accounting for Government Grants and Disclosure of Government Assistance.

14. The Finance Order no. 1802/2014 regarding the Approval of the Accounting Regulations on the annual individual and consolidated financial statements. 